
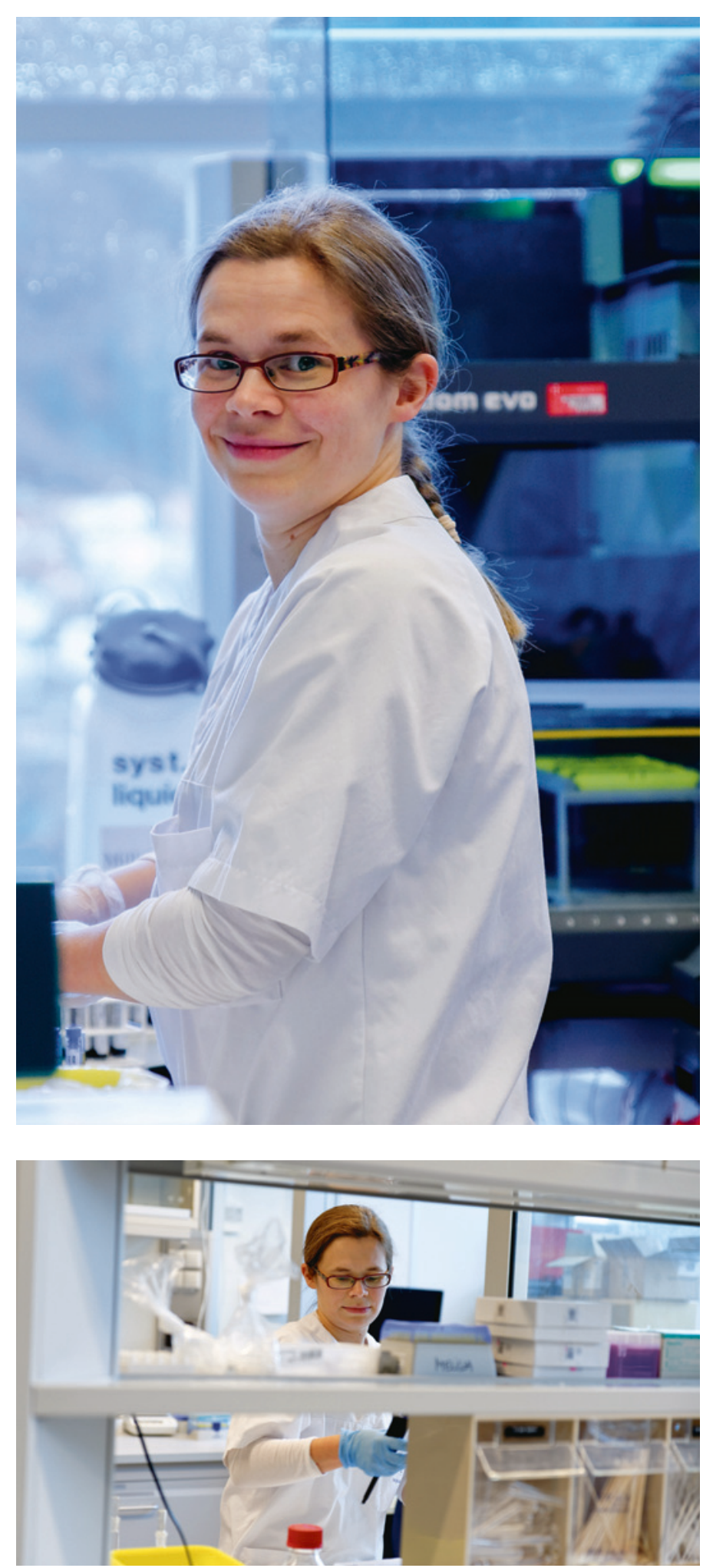

Foto: Magne Sandnes

\section{Fra laboratorieverdenen}

Kristin Viste er ph.d. og lege i spesialisering i medisinsk biokjemi. Hun jobber som konstituert overlege ved Hormonlaboratoriet ved Haukeland universitetssykehus.

\section{Skjer det noe interessant innen medisinsk biokjemi for tiden? Fortell.}

Spør du ti medisinske biokjemikere om viktige fremskritt i faget, får du ti ulike svar, avhengig av spesialinteresse - det kan være alt fra bruk av nye koagulasjonsanalyser og ny og bedre tolking av «gamle» hjertemarkører til nye kvalitetskontrollsystemer. Jeg jobber med endokrinologisk biokjemi, og her er innføring av massespektrometriske (LC-MS/MS) metoder et stort fremskritt som gjør at vi nå kan bestemme hormonkonsentrasjoner mer direkte enn ved antistoffbaserte analysemetoder. Spriket mellom to ulike antistoffbaserte metoder kan være stort, mens to LC-MS/MS-analyser gir mer like svar $-i$ alle fall $i$ teorien. Dette gjør at referanseområder og aksjonsgrenser lettere kan overføres mellom laboratoriene. I tillegg kan vi måle flere hormoner samtidig. Dette er særlig nyttig der vi har lite prøvemateriale, som for eksempel hos barn.

\section{Vil du anbefale en ny og spennende artikkel?}

Ja, en artikkel som ble publisert i Clinical Biochemistry i 2013 som utgikk fra Caliper-studien. Her samlet de inn prøver fra mange barn og analyserte steroidhormoner ved hjelp av LC-MS/MS eller en LCMSMS-metode (1). Man kan bruke blodgivere og laboratorieansatte for å bestemme referanseområde hos voksne, men gode barnereferanseområder, som man finner i denne artikkelen, er sjeldne. Vi bruker disse referanseområdene for å tolke våre barneprøver.

\section{Hva er ditt favoritthjelpemiddel på jobb?}

Jeg skal ikke underslå at kaffekoppen er en trofast følgesvenn ved omfattende og konsentrasjonskrevende utredninger. På vakt finner jeg god informasjon om analyser i brukerhåndbokappen til Norsk selskap for medisinsk biokjemi.

\section{Anbefalt litteratur}

1. Kyriakopoulou L, Yazdanpanah M, Colantonio DA et al. A sensitive and rapid mass spectrometric method for the simultaneous measurement of eight steroid hormones and CALIPER pediatric reference intervals. Clin Biochem 2013; 46: 642-51.

Har du tips til personer vi kan intervjue? Ta kontakt med lise.morkved.helsingen@legeforeningen.no 